\title{
Altered microRNA expression profiles are involved in resistance to low-dose ionizing radiation in the absence of BMI1 in human dermal fibroblasts
}

\author{
SEUNGHEE BAE ${ }^{1}$, KARAM KIM ${ }^{1}$, HWA JUN CHA ${ }^{1}$, YEONGMIN CHOI ${ }^{1}$, SHANG HUN SHIN ${ }^{1}$, IN-SOOK AN ${ }^{1}$, \\ JAE HO LEE ${ }^{2}$, JIE-YOUNG SONG $^{3}$, KWANG HEE YANG $^{4}$, SEON YOUNG NAM $^{4}$ and SUNGKWAN AN ${ }^{1}$ \\ ${ }^{1}$ Molecular-Targeted Drug Research Center and Korea Institute for Skin and Clinical Sciences, Konkuk University, \\ Seoul 143-701; ${ }^{2}$ Laboratory of Molecular Oncology, Cheil General Hospital and Women's Healthcare Center, \\ Kwandong University, College of Medicine, Seoul 100-380; ${ }^{3}$ Division of Radiation Cancer Science, \\ Korea Institute of Radiological and Medical Sciences, Seoul 139-706; ${ }^{4}$ Radiation Effect Research Team, \\ Radiation Health Research Institute, Korea Hydro \& Nuclear Power Co., Ltd., Seoul 132-703, Republic of Korea
}

Received April 26, 2014; Accepted June 17, 2014

DOI: $10.3892 /$ ijo.2014.2542

\begin{abstract}
The polycomb group RING finger protein, B-cell-specific moloney murine leukemia virus integration site 1 (BMI1), has emerged as a key regulator of cell proliferation, cell cycle, cell immortalization, chemoresistance and radioresistance. Although the radioresistant effect of BMI1 has been thoroughly investigated, the effectiveness of this factor on low-dose radiation (LDR) resistance has not been explored. Here, we demonstrate that BMI1 is not critical for altering cell viability or cell growth in response to LDR, but BMI1 changes cellular gene expression profiles in response to LDR. Normal human dermal fibroblasts (NHDFs) stably expressing BMI1 short hairpin RNA (shRNA) did not exhibit changes in cell viability or cell cycle distribution assays following exposure to $0.1 \mathrm{~Gy}$ of $\gamma$-radiation. However, microRNA (miRNA) microarrays revealed that a lack of BMI1 leads to changes in miRNA expression in response to LDR. Bioinformatics analyses demonstrated that predicted target genes of the altered miRNAs are functionally involved in both negative and positive regulation of cell growth, cell proliferation, cell cycle and apoptosis. Therefore, these results indicate that low radiosensitivity even in the absence of the radioresistant factor BMI1 is related with the altered miRNA expression profiles in NHDF.
\end{abstract}

Correspondence to: Professor Sungkwan An, Molecular-Targeted Drug Research Center and Korea Institute for Skin and Clinical Sciences, Konkuk University, 120 Neungdong-ro, Gwangjin-gu, Seoul 143-701, Republic of Korea

E-mail: ansfgrc@konkuk.ac.kr

Key words: B-cell-specific moloney murine leukemia virus integration site 1 , low-dose radiation, microRNA, dermal fibroblasts, radioresponse

\section{Introduction}

B-cell-specific moloney murine leukemia virus integration site 1 (BMI1), also known as polycomb group RING finger protein 4 (PCGF4), is a member of the polycomb group protein family. Accumulating evidence indicates that BMI1 plays a critical role in the regulation of cell proliferation, cell cycle, cell immortalization and chemoresistance (1-4), and therefore, BMI1 has been considered as a novel target for cancer therapy (3). Indeed, in vivo studies have demonstrated that the protein level of BMI1 is elevated in many types of cancers (5-7). Additionally, numerous molecular studies have demonstrated the function of BMI1 as a transcriptional regulator of gene expression $(8,9)$. The INK4a/ARF tumor suppressor locus, which encodes tumor suppressor proteins p16 $6^{\mathrm{INK} 4 \mathrm{a}}$ and $\mathrm{p} 14^{\mathrm{ARF}}$, is significantly repressed by BMI1 (8). In studies using cDNA microarray analysis, BMI1 was found to regulate the expression of hundreds of downstream target genes, including genes that are involved in both differentiation and development (9). Furthermore, BMI1 represses the expression of microRNAs (miRNAs), such as let-7i, which targets the mitotic kinase Aurora A (10). Other studies have revealed that BMI1 contributes to radiation resistance (radioresistance) of normal and cancer cells (11-14); therefore, BMI1 expression is a predictive factor for poor patient prognosis (4). Notably, BMI1 overexpression significantly reduces the ionizing radiation-mediated DNA double-strand break and cytotoxic effects in vitro and in vivo $(12,13)$; however, the effectiveness of BMI1 against irradiation has been studied at relatively high doses ( $\geq 1 \mathrm{~Gy}$ ). Therefore, whether BMI1 influences cell growth upon cellular exposure to low doses of ionizing radiation $(\leq 0.1 \mathrm{~Gy})$, remains unknown.

Understanding the cellular effects of exposure to low-dose radiation (LDR) in human cells is important, as humans are continuously exposed to LDR from nature, medical devices, nuclear energy production sources and other industrial uses of ionizing radiation (15). Research into the biological 
effects of LDR exposure is summarized into 3 categories: the linear non-threshold (LNT) model, threshold model and radioadaptive model (16). Because LDR has no immediate noticeable effects on humans, the biological effects of LDR have typically been estimated by extrapolation based on the biological effects of high-dose radiation (LNT model) (17); however, this model has become controversial because cellular responses can be very different following LDR compared to responses to high radiation doses (18). Venkat et al demonstrated that pre-exposure to LDR in the range of about $1 \mathrm{cGy}$ reduced the frequency of micronuclei in binucleated cells induced by $100 \mathrm{cGy}$, modulating the radioadaptive responses in human lymphocytes (19). This phenomenon clearly supports the radioadaptive model (20); however, other studies have shown that LDR induces hyper-radiosensitivity (HRS) and increases radioresistance responses (IRR) in cells (21). These studies revealed that mammalian cells exhibit HRS to radiation doses of less than $0.3 \mathrm{~Gy}$, whereas in the 0.3 -to-0.6 Gy dose range, a more radioresistant response is observed (21). Clearly, all of the models for the LDR responses are not fully understood.

miRNAs, which are small non-coding RNAs with lengths of 19-24 nucleotides (22), play important roles in several biological processes, including cell proliferation, differentiation, apoptosis and stress resistance, via regulation of gene expression pathways (23). In our previous study, we found that the miRNA expression profiles are altered by high-dose gamma-irradiation ( $\geq 0.5 \mathrm{~Gy}$ ), implicating the alteration of miRNA expression profiles in the irradiation response (24-26). Other studies also demonstrated a role for miRNAs in radiation response. Specifically, miR-185 enhances ionizing radiation-induced apoptosis through regulation of the ataxia telangiectasia protein-related (ATR) pathway (27). In addition, ionizing radiation-inducible miR-193a-3p directly targets myeloid cell leukemia 1 (MCL-1) and induces apoptosis (28). These studies revealed alterations of miRNA expression profiles and functions at relatively high doses of radiation. Thus, the interplay between LDR response and miRNAs is not fully understood. Here, we investigated how BMI1 and miRNAs influence the LDR response.

\section{Materials and methods}

Cell culture and irradiation. Normal human dermal fibroblast (NHDF) cells were purchased from Lonza (Basel, Switzerland) and cultured in Dulbecco's modified Eagle's medium (DMEM, Gibco, Life Technologies, Grand Island, NY, USA) containing $10 \%$ fetal bovine serum (FBS, Sigma-Aldrich, St. Louis, $\mathrm{MO}, \mathrm{USA}$ ) at $37^{\circ} \mathrm{C}$ in a humidified chamber with $5 \% \mathrm{CO}_{2}$. To evaluate the patterns of cell cycle effects and miRNA expression, $7 \times 10^{5}$ cells were seeded in a $60-\mathrm{mm}$ culture plate and grown for $24 \mathrm{~h}$. These cells then were irradiated with $0.1 \mathrm{~Gy}$ of $\gamma$-radiation using a MDI-KIRAMS 137 irradiator $\left({ }^{137} \mathrm{Cs} \gamma\right.$-ray source, KIRAMS, Seoul, Korea).

Generation of stable BMI1-knockdown NHDFs. A BMI1 stable knockdown cell line was established using lentiviral gene transfer. The plasmid shBMI1-pLKO.1 puro was purchased from Sigma-Aldrich. The 293T cells were co-transfected with shBMI1-pLKO.1 puro lentiviral transfer vector, pCMV-dR8.2
(Addgene, Cambridge, MA, USA), and pCMV-VSV-G plasmid (Addgene). Approximately $48 \mathrm{~h}$ after transfection, recombinant lentivirus particle-containing medium was collected and used to infect NHDFs. Infected NHDFs were incubated with the growth culture medium containing puromycin $(1 \mu \mathrm{g} / \mathrm{ml})$ to select BMI1-knockdown cells.

Western blot analysis. Cell lysates were prepared in SDS lysis buffer [1\% (w/v) SDS, 20 mM Tris-HCl pH 7.4, 20 mM EDTA]. Protein samples were subjected to SDS-PAGE and then transferred to a nitrocellulose membrane (Whatman International Ltd., Maidstone, UK). Membranes were incubated in a solution of $5 \%(\mathrm{w} / \mathrm{v})$ skim milk in Tris-buffered saline and Tween-20 (TBST) buffer and probed with anti- $\beta$-actin IgG (Sigma-Aldrich) or anti-BMI1 IgG antibodies (Santa Cruz Biotechnology, Santa Cruz, CA, USA).

Cell viability assay. The effect of $\gamma$-radiation (0.1 Gy) on viability was determined using a 3-[4,5-dimethylthiazol2-yl]-2,5 diphenyl tetrazolium bromide (MTT) assay (Sigma-Aldrich), according to the manufacturer's instructions. Briefly, seeded cells were irradiated with 0.1 Gy of $\gamma$-radiation. After 6 and $24 \mathrm{~h}$ of additional incubation, MTT solution was added to the irradiated cells, and the samples were incubated for $1 \mathrm{~h}$. Media was removed, and the blue formazan crystals trapped in cells were dissolved in dimethyl sulfoxide (DMSO, Sigma-Aldrich). Cell viability was measured using an iMark plate reader (Bio-Rad, Hercules, CA, USA) at $590 \mathrm{~nm}$ with a reference filter of $620 \mathrm{~nm}$. All results are presented as the mean percentages \pm standard deviation (SD) of three independent experiments. A p-value of $<0.05$, as determined by Student's t-test, was considered significant.

Analysis of cell cycle by flow cytometry. Cell cycle distribution was determined using FACS (Fluorescence Activated Cell Sorting) analysis. Irradiated cells were fixed by the addition of cold $70 \%$ ethanol overnight. Following fixation, cells were washed with cold PBS and then stained with propidium iodide (PI) staining solution $(50 \mu \mathrm{g} / \mathrm{ml} \mathrm{PI}, 0.5 \%$ Triton $\mathrm{X}-100$, and $100 \mu \mathrm{g} / \mathrm{ml} \mathrm{RNase)}$ at $37^{\circ} \mathrm{C}$ for $1 \mathrm{~h}$. The PI fluorescence intensity was detected using a BD FACSCalibur flow cytometer (BD Biosciences, San Jose, CA, USA). The mean PI fluorescence intensity was obtained from 10,000 cells using the FL2-H channel.

RNA purification and microarray analysis of miRNA expression. Total RNAs were purified using TRIzol reagent (Life Technologies) according to the manufacturer's protocol. The purity and integrity of the RNA sample was assessed using the ratio of absorbance at 230, 260 and $280 \mathrm{~nm}$ by MaestroNano ${ }^{\circledR}$, a micro-volume spectrophotometer (Maestrogen, Las Vegas, $\mathrm{NV}$, USA) and Agilent 2100 Bioanalyzer ${ }^{\circledR}$ (Agilent Technologies, Santa Clara, CA, USA). Microarray analyses were performed using SurePrint G3 Human V16 miRNA $8 \times 60 \mathrm{~K}$ microarray kit (Agilent Technologies), as previously described (29). Briefly, $50 \mathrm{ng}$ of purified RNA was treated with calf intestine alkaline phosphatase prior to labeling with cyanine 3-cytidine bisphosphate (3-pCp). The labeled RNA was hybridized with the microarray kit in the Agilent Microarray Hybridization Chamber (Agilent Technologies) 
A

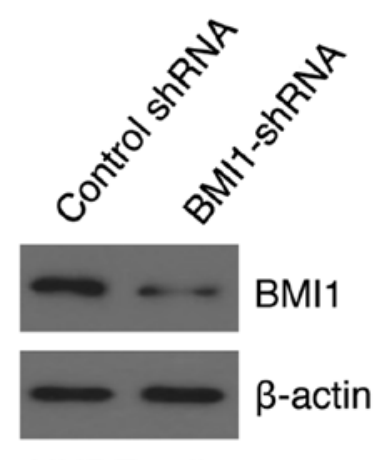

NHDF cells
B
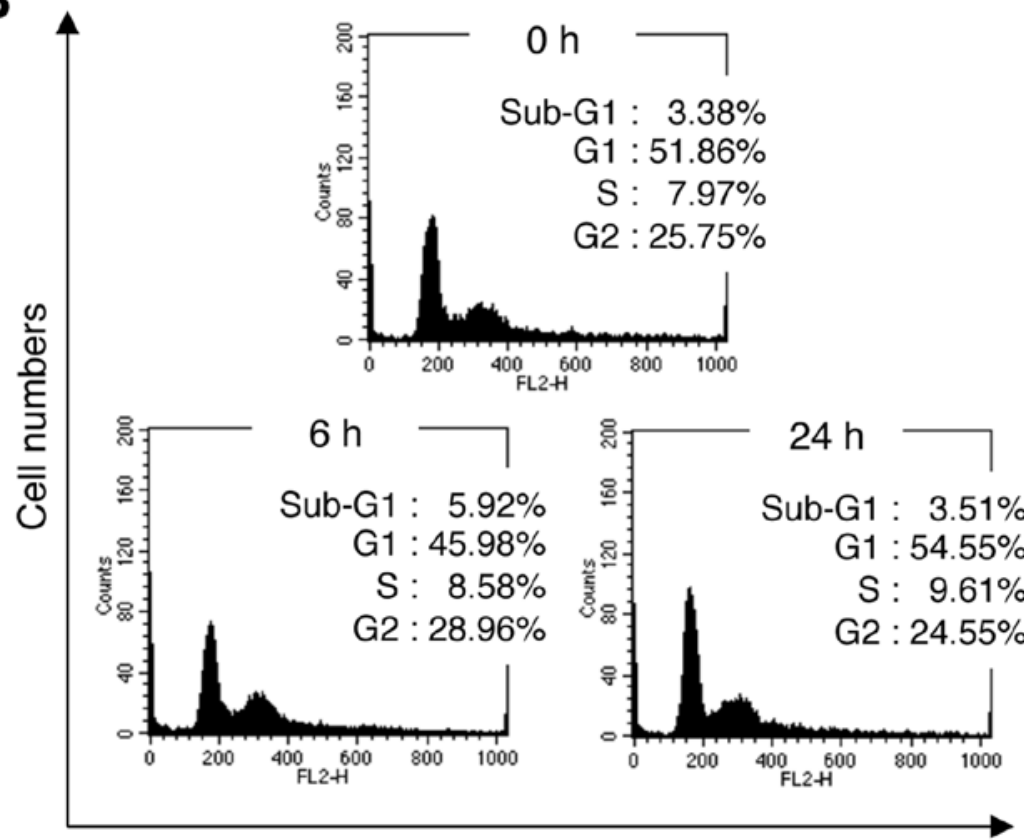

PI intensity

Figure 1. LDR does not induce cell cycle arrest in BMI1-knockdown NHDFs. (A) Western blot analysis of BMI1-knockdown NHDFs. NHDFs were infected with shBMI1-expressing lentivirus, and cellular extract was probed with anti-BMI1 antibody. As a loading control, the membrane was probed for $\beta$-actin. (B) Cell cycle patterns of BMI1-knockdown NHDFs after irradiation. Cells were irradiated with 0.1 Gy of $\gamma$-radiation. After 6 and 24 h of additional incubation, cells were fixed and stained with PI-staining solution. The cell cycle was evaluated using flow cytometry analysis.

for $20 \mathrm{~h}$. The fluorescence intensities of the labeled miRNA samples on the microarray were measured using Scanner and Feature Extraction software (Agilent Technologies). The digitalized fluorescence intensities were analyzed using GeneSpring GX version 11.5 (Agilent Technologies). The raw data were filtered using FLAG and t-tests and analyzed using the fold-change analysis, which was conducted based on a factor of a 2.0-fold difference between the two groups (i.e., non-irradiated control cells and irradiated cells).

Target prediction and bioinformatics analysis of miRNAs. To assess the biological significance of the altered miRNA expression, three bioinformatic analyses were performed: determination of putative target genes of the miRNAs using the DIANA-microT bioinformatic software tool (http://diana. imis.athena-innovation.gr/DianaTools/index.php?r=microT_ CDS/index) (30), prediction of the target-related cellular pathways using the Kyoto Encyclopedia of Genes and Genomes (KEGG) pathways and DAVID (Database for Annotation, Visualization and Interrogate Discovery, http:// david.abcc.ncifcrf.gov/home.jsp) bioinformatics resources v6.7 according to the developer's protocol (31), and categorization of target genes with specific biological functions using the AmiGO Gene Ontology (GO) analysis tool (http://amigo. geneontology.org/amigo). The prediction of target genes was limited by setting the value of the threshold to 0.8 in the DIANA-microT tool. The 'KEGG_pathway' category was processed by setting the threshold of EASE score, a modified Fisher Exact p-value, to 0.1, and involved KEGG pathways that displayed a value $>1 \%$ (percentage of involved target genes/total target genes in each pathway) were selected. GO analysis was performed in eight categories for positive or negative regulation of apoptotic processes, cell growth, cell proliferation and cell cycle.

\section{Results}

Cell viability and cell growth changes are not induced by 0.1 Gy $\gamma$-radiation in BMI1-knockdown NHDFs. To evaluate the possible effect of BMI1 in resistance to LDR, we first generated BMI1 shRNA- or control shRNA-expressing NHDFs using a lentiviral system. After infection, the cells were treated with selection marker (puromycin) to obtain stable clones. The BMI1 protein level was clearly reduced in shBMI1-expressing clones, thereby confirming efficient knockdown (Fig. 1A). Using these stable clones, we then examined alterations in cell viability at 6 and $24 \mathrm{~h}$ after irradiation with 0.1 Gy of $\gamma$-radiation. Unexpectedly, no significant changes in cell viability were detected (data not shown), indicating that BMI1 may not be an essential regulator of LDR resistance in NHDFs. We next performed PI staining-based cell cycle analysis following irradiation. The cell cycle patterns of the irradiated cells at 6 and $24 \mathrm{~h}$ after irradiation were not significantly different from that of control cells (Fig. 1B). Although the proportion of cells in G1 and $\mathrm{G} 2 / \mathrm{M}$ phase were slightly changed after $6 \mathrm{~h}$ by 5.88 and $-3.21 \%$, respectively, these values returned to baseline $(0 \mathrm{~h})$ at $24 \mathrm{~h}$ post-irradiation. Therefore, these results suggest that cells were only slightly sensitive to LDR even in the absence of BMI1 expression in NHDFs. 
A

\begin{tabular}{|c|c|c|}
\hline Lenti-shBMl1 & - & + \\
\hline \multicolumn{3}{|l|}{ hsa-miR-101-3p } \\
\hline hsa-miR-1181 & & \\
\hline hsa-miR-1208 & & \\
\hline \multicolumn{3}{|l|}{ hsa-miR-1225-3p } \\
\hline \multicolumn{3}{|l|}{ hsa-miR-1226-5p } \\
\hline \multicolumn{3}{|l|}{ hsa-miR-1228-3p } \\
\hline \multicolumn{3}{|l|}{ hsa-miR-1234 } \\
\hline \multicolumn{3}{|l|}{ hsa-miR-1238 } \\
\hline \multicolumn{3}{|l|}{ hsa-miR-125a-3p } \\
\hline \\
\hline \multicolumn{3}{|l|}{ hsa-miR-1275 } \\
\hline \multicolumn{3}{|l|}{ hsa-miR-128 } \\
\hline \multicolumn{3}{|l|}{ hsa-miR-1281 } \\
\hline \multicolumn{3}{|l|}{ hsa-miR-1288 } \\
\hline \multicolumn{3}{|l|}{ hsa-miR-1290 } \\
\hline \multicolumn{3}{|l|}{ hsa-miR-130b-3p } \\
\hline \multicolumn{3}{|l|}{ hsa-miR-132-3p } \\
\hline \multicolumn{3}{|l|}{ hsa-miR-134 } \\
\hline \multicolumn{3}{|l|}{ hsa-miR-135a-3p } \\
\hline \\
\hline \multicolumn{3}{|l|}{ hsa-miR-138-5p } \\
\hline \multicolumn{3}{|l|}{ hsa-miR-138-2-3p } \\
\hline \multicolumn{3}{|l|}{ hsa-miR-140-3p } \\
\hline \multicolumn{3}{|l|}{ hsa-miR-140-5p } \\
\hline \multicolumn{3}{|l|}{ hsa-miR-148b-3p } \\
\hline \multicolumn{3}{|l|}{ hsa-miR-150-3p } \\
\hline \multicolumn{3}{|l|}{ hsa-miR-151a-3p } \\
\hline hsa-miR-154-3p & & \\
\hline hsa-miR-17-3p & & \\
\hline hsa-miR-181a-3p & & \\
\hline hsa-miR-1825 & & \\
\hline hsa-miR-185-5p & & \\
\hline hsa-miR-186-5p & & \\
\hline hsa-miR-188-5p & & \\
\hline hsa-miR-18a-5p & & \\
\hline hsa-miR-18b-5p & & \\
\hline hsa-miR-191-3p & & \\
\hline hsa-miR-193a-5p & & \\
\hline hsa-miR-1973 & & \\
\hline hsa-miR-210 & & \\
\hline hsa-miR-28-5p & & \\
\hline hsa-miR-299-3p & & \\
\hline hsa-miR-301a-3p & & \\
\hline
\end{tabular}

108 upregulated miRNAs

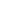

hsa-miR-3132

hsa-miR-3141

hsa-miR-3156-5p

hsa-miR-3188

hsa-miR-32-5p

hsa-miR-324-5p

hsa-miR-329

hsa-miR-337-5p

hsa-miR-33b-3p

hsa-miR-342-3p

hsa-miR-34c-5p

hsa-miR-361-5p

hsa-miR-3646

hsa-miR-3648

hsa-miR-3653

hsa-miR-3656

hsa-miR-3663-3p

hsa-miR-369-3p

hsa-miR-369-5p

hsa-miR-371a-5p

hsa-miR-376a-5p

hsa-miR-378b

hsa-miR-379-5p

hsa-miR-382-5p

hsa-miR-3911

hsa-miR-409-3p

hsa-miR-410

hsa-miR-411-5p

hsa-miR-423-5p

hsa-miR-425-3p

hsa-miR-4252

hsa-miR-4257

hsa-miR-4271

hsa-miR-4298

hsa-miR-4306

hsa-miR-4313

hsa-miR-4317

hsa-miR-432-5p

hsa-miR-4327

hsa-miR-450a-5p

hsa-miR-454-3p

hsa-miR-483-5p (continued)
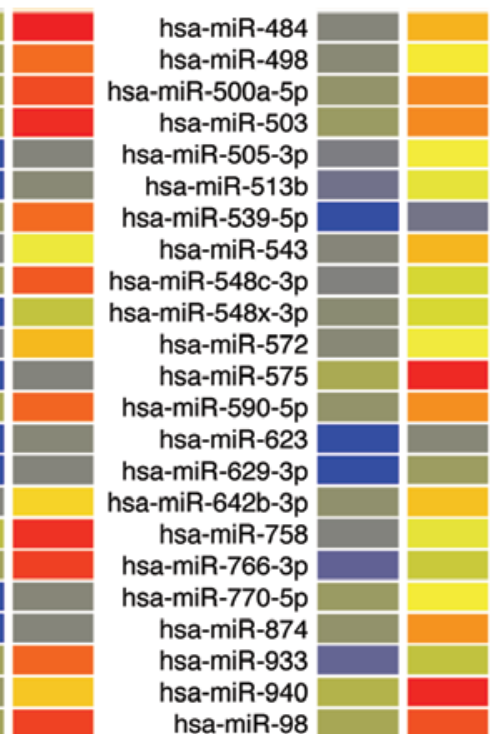

hsa-miR-98

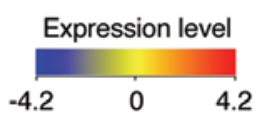

B

43 downregulated miRNAs

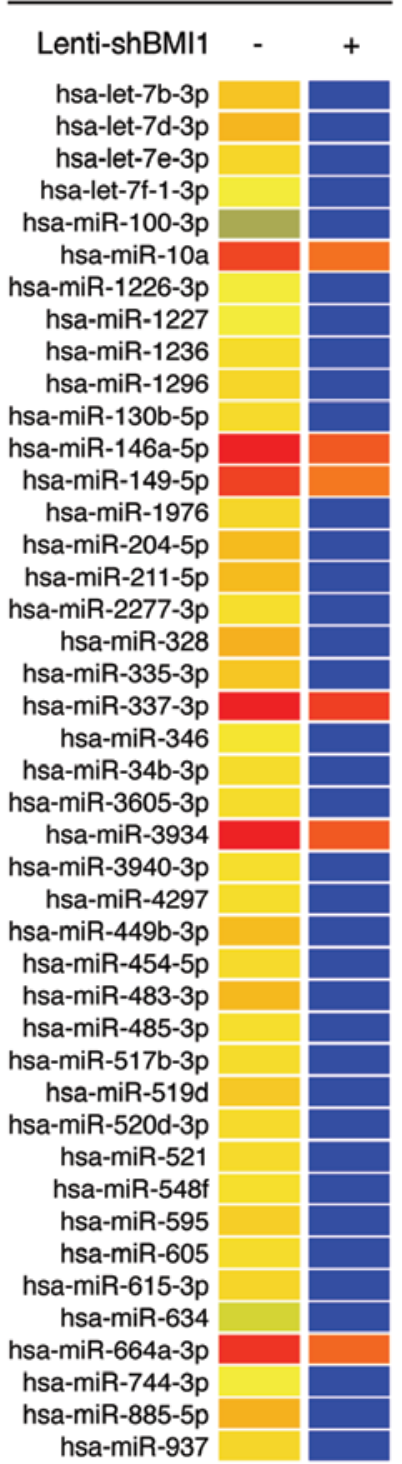

Figure 2. Altered miRNA expression profiles in BMI1-knockdown NHDFs. Microarray analysis for miRNA expression patterns in BMI1-knockdown NHDFs compared to control NHDFs. Heat-map of deregulated miRNAs that have 2-fold higher (upregulated) or lower (downregulated) Cy3 fluorescence.

Altered miRNA expression profiles in BMII-knockdown $N H D F$ in response to $L D R$. Although our results (Fig. 1) suggest a dispensable role for BMI1 in radioresistance to LDR, these studies did not fully exclude the possibility that such a modest radiosensitivity was caused by alteration of cellular pathways in BMI1-knockdown NHDFs. Recent evidence supports the role of BMI1 as a transcription factor engaged in cell proliferation, cell cycle, cell immortalization, chemoresistance and radioresistance (1-4,12). Notably, numerous cDNA microarray studies have sought to identify BMI1 target genes $(14,32,33)$; however, miRNA microarray-based analysis of BMI1 putative target miRNAs has not yet been described. We first compared the miRNA expression profiles between control and BMI1-knockdown NHDFs not exposed to LDR. As shown in Fig. 2, 108 and 43 miRNAs are up- and downregulated more than 2-fold, respectively, in BMI1- knockdown NHDFs compared to control cells, indicating that BMI1 regulates the expression of specific miRNAs. Notably, expression levels of miR-17-3p, miR-1825 and miR-33b-3p were significantly increased by $81.71-, 61.18$ - and 30.62 -fold, respectively, while expression levels of miR-328, miR-885-5p and let-7d-3p were significantly downregulated by $23.53-$, 23.12- and 21.69-fold, respectively.

Next, we analyzed the LDR-induced alterations in miRNA expression profiles in BMI1-knockdown NHDFs. At 6 and $24 \mathrm{~h}$ after irradiation with 0.1 Gy of $\gamma$-radiation, total RNA was purified, and then miRNA microarray assays were performed. Although LDR induced minimal changes in cell viability and cell cycle distribution in BMI1-knockdown NHDFs (Fig. 1), we unexpectedly found that the expression of numerous miRNAs was altered more than 2-fold in the irradiated BMI1-knockdown NHDFs (Fig. 3). Specifically, 
A

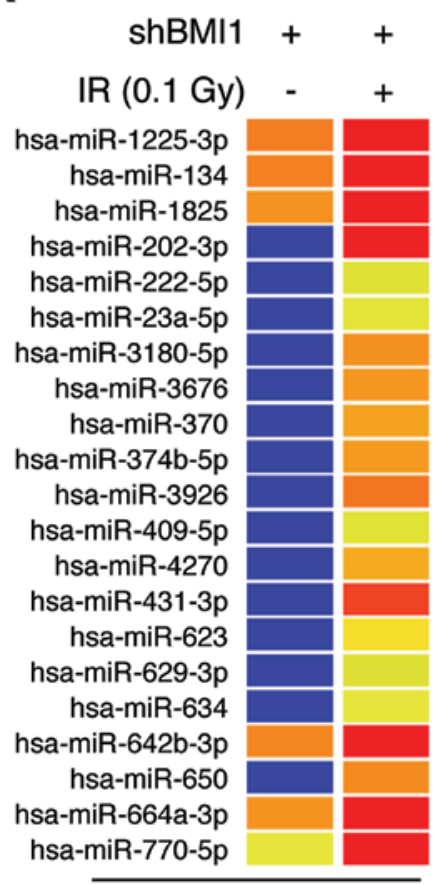

21 upregulated miRNAs

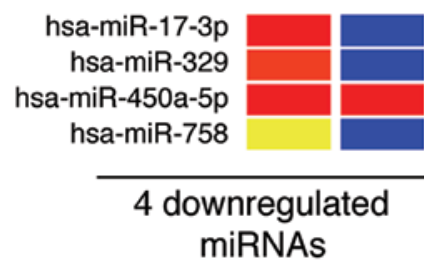

B

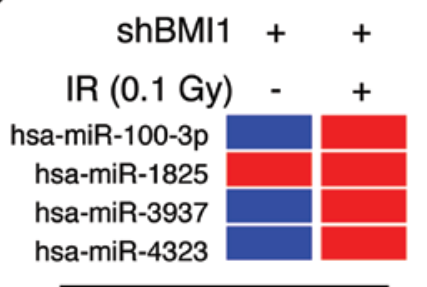

4 upregulated miRNAs
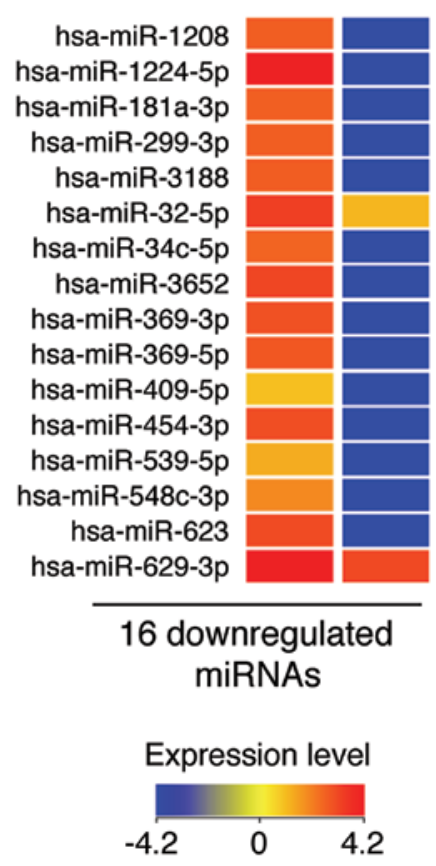

Figure 3. Altered patterns of miRNA expression profiles in BMI1-knockdown NHDF cells after irradiation with 0.1 Gy of $\gamma$-radiation. Heat map showing the altered miRNA expression profile in BMI1-knockdown NHDFs at (A) 6 and (B) $24 \mathrm{~h}$ after irradiation. The heat-map shows dysregulated miRNAs that have 2-fold higher (upregulated) or lower (downregulated) $\mathrm{Cy} 3$ fluorescence in irradiated cells compared with non-irradiated control cells.

LDR upregulated 21 specific miRNAs and downregulated 4 miRNAs at the 6-h time point in BMI1-knockdown NHDFs (Fig. 3A). Also, 4 and 16 miRNAs were significantly upregulated and downregulated, respectively, by LDR at $24 \mathrm{~h}$ after irradiation (Fig. 3B). The full data are shown in Tables I and II. Among these miRNAs, miR-202-3p and miR-4323 were the most upregulated miRNAs by 81.90 - and 66.47 -fold at 6 and $24 \mathrm{~h}$ after irradiation, respectively, and miR-758 and miR-1224-5p were the most downregulated miRNAs (21.20and 106.85-fold, respectively) (Tables I and II). Overall, these data suggest that BMI1 altered miRNA expression in response to LDR.

Specific miRNA expression signatures were found for $L D R$ and BMII knockdown in NHDF cells. In total, we found 108 upregulated and 43 downregulated miRNAs in BMI1knockdown NHDFs and 21 upregulated and 4 downregulated miRNAs in BMI1-knockdown cells $6 \mathrm{~h}$ post-irradiation. In addition, 4 and 16 miRNAs were upregulated and downregulated, respectively, in these cells $24 \mathrm{~h}$ post-irradiation (Fig. 4A). Seven miRNAs were upregulated in both BMI1-knockdown cells and in cells $6 \mathrm{~h}$ post-irradiation (Fig. 4B, upper left). In particular, 2 of the 21 miRNAs were found to be differentially expressed in either BMI1-knockdown cells or in BMI1knockdown cells $6 \mathrm{~h}$ post-irradiation (Fig. 4B, upper left). These results also indicated that 2 upregulated miRNAs were specific to BMI1-knockdown NHDFs at $6 \mathrm{~h}$ post-irradiation (Fig. 4B, upper left). Interestingly, no downregulated miRNAs were specific to the profile of these cells at $6 \mathrm{~h}$ post-irradiation (Fig. 4B, lower left). Similarly, the differentially expressed miRNAs in BMI1-knockdown NHDFs at $24 \mathrm{~h}$ post-irradiation were also shared, in part, with BMI knockdown-induced miRNA alterations (Fig. 4B, upper and lower right). The group of differentially expressed miRNAs in BMI1-knockdown NHDFs and the miRNAs upregulated in BMI1-knockdown NHDFs 24 h post-irradiation had 2 miRNAs in common, and thus, only a subset of 150 and 2 miRNAs were unique to each group, respectively (Fig. 4B, upper). Furthermore, the sets of altered miRNAs in BMI1-knockdown NHDFs 24 h post-irradiation and BMI1-knockdown NHDFs also had 13 miRNAs in common, and only a subset of 3 and 139 miRNAs were unique to each group, respectively (Fig. 4, lower). Overall, these results indicate that knockdown of LDR and BMI1 affects both unique and shared miRNAs in NHDFs. 
Table I. The miRNAs that exhibited significant changes in expression in BMI1-knockdown NHDF cells $6 \mathrm{~h}$ after irradiation with low-dose radiation $(0.1 \mathrm{~Gy}){ }^{\mathrm{a}}$

\begin{tabular}{|c|c|c|c|c|c|c|c|}
\hline Gene name & Fold change & Direction & Chr. & Gene name & Fold change & Direction & Chr. \\
\hline hsa-miR-1225-3p & 2.2 & Up & $\operatorname{chr} 16$ & hsa-miR-431-3p & 54.8 & Up & $\operatorname{chr} 14$ \\
\hline hsa-miR-134 & 2.0 & Up & chr14 & hsa-miR-623 & 29.0 & Up & $\operatorname{chr} 13$ \\
\hline hsa-miR-1825 & 2.0 & Up & $\operatorname{chr} 20$ & hsa-miR-629-3p & 18.4 & Up & $\operatorname{chr} 15$ \\
\hline hsa-miR-202-3p & 81.9 & Up & chr10 & hsa-miR-634 & 21.6 & Up & $\operatorname{chr} 17$ \\
\hline hsa-miR-222-5p & 18.8 & $\mathrm{Up}$ & $\operatorname{chrX}$ & hsa-miR-642b-3p & 2.2 & $\mathrm{Up}$ & $\operatorname{chr} 19$ \\
\hline hsa-miR-23a-5p & 20.3 & Up & $\operatorname{chr} 19$ & hsa-miR-650 & 40.2 & Up & $\operatorname{chr} 22$ \\
\hline hsa-miR-3180-5p & 39.4 & $\mathrm{Up}$ & $\operatorname{chr} 16$ & hsa-miR-664a-3p & 2.2 & Up & chr1 \\
\hline hsa-miR-3676 & 38.5 & Up & $\operatorname{chr} 17$ & hsa-miR-770-5p & 3.2 & Up & $\operatorname{chr} 14$ \\
\hline hsa-miR-370 & 36.8 & $\mathrm{Up}$ & $\operatorname{chr} 14$ & hsa-miR-17-3p & -46.9 & Down & $\operatorname{chr} 13$ \\
\hline hsa-miR-374b-5p & 38.1 & $\mathrm{Up}$ & $\operatorname{chrX}$ & hsa-miR-329 & -38.4 & Down & $\operatorname{chr} 14$ \\
\hline hsa-miR-3926 & 44.1 & Up & chr8 & hsa-miR-450a-5p & -2.1 & Down & $\operatorname{chrX}$ \\
\hline hsa-miR-409-5p & 19.6 & Up & $\operatorname{chr} 14$ & hsa-miR-758 & -21.2 & Down & chr14 \\
\hline hsa-miR-4270 & 35.6 & Up & chr3 & & & & \\
\hline
\end{tabular}

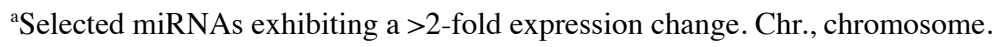

Table II. The miRNAs that exhibited significant changes in BMI1-knockdown cells $24 \mathrm{~h}$ after irradiation with low-dose radiation (0.1 Gy). ${ }^{\mathrm{a}}$

\begin{tabular}{lcclcrrr}
\hline Gene name & Fold change & Direction & Chr. & Gene name & Fold change & Direction & Chr. \\
\hline hsa-miR-100-3p & 30.5 & Up & chr11 & hsa-miR-34c-5p & -45.5 & Down & chr11 \\
hsa-miR-1825 & 2.2 & Up & chr20 & hsa-miR-3652 & -55.7 & Down & chr12 \\
hsa-miR-3937 & 56.9 & Up & chrX & hsa-miR-369-3p & -51.6 & Down & chr14 \\
hsa-miR-4323 & 66.5 & Up & chr19 & hsa-miR-369-5p & -49.3 & Down & chr14 \\
hsa-miR-1208 & -47.2 & Down & chr8 & hsa-miR-409-5p & -26.1 & Down & chr14 \\
hsa-miR-1224-5p & -106.9 & Down & chr3 & hsa-miR-454-3p & -52.7 & Down & chr17 \\
hsa-miR-181a-3p & -46.8 & Down & chr1 & hsa-miR-539-5p & -29.3 & Down & chr14 \\
hsa-miR-299-3p & -47.4 & Down & chr14 & hsa-miR-548c-3p & -36.0 & Down & chr12 \\
hsa-miR-3188 & -47.6 & Down & chr19 & hsa-miR-623 & -54.0 & Down & chr13 \\
hsa-miR-32-5p & -2.1 & Down & chr9 & hsa-miR-629-3p & -2.2 & Down & chr15 \\
\hline
\end{tabular}

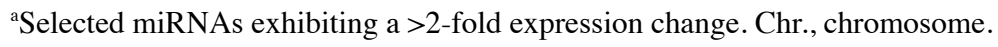

Bioinformatics analysis of altered miRNAs from BMI1-knockdown NHDF in response to LDR. We next examined the biological influence of the observed altered miRNAs. Because biological functions of miRNAs are mainly determined by the regulation of their specific target mRNAs, the putative target of each miRNA was first predicted using the DIANA-microT-CDS (v5.0) web-based bioinformatics tool. The prediction threshold, which is a cut-off value for presented prediction and ranges from 0.3 to 1.0, was fixed at 0.8. Following prediction, a Gene Ontology and KEGG pathway annotation of the miRNA targets were performed using the AmiGO and DAVID bioinformatics tools. Using AmiGO, we categorized the target genes into eight types according to biological function: positive and negative regulation of the apoptotic process, cell growth, cell proliferation and cell cycle. The target genes for the miRNAs that were upregulated in BMI1-knockdown NHDFs at 6 h post-irradiation (written as '6PB-NHDFs') are involved in both positive and negative regulation of the four biological functions. Similarly, the target genes for the altered miRNAs in the BMI1-knockdown NHDFs at $24 \mathrm{~h}$ post-irradiation (written as '24PB-NHDFs') are also involved in both positive and negative regulation of the four biological functions (Fig. 5). Interestingly, the targets of the upregulated miRNAs in 6BP-NHDFs are largely involved in these processes; however, the targets of the downregulated miRNAs in 24BP-NHDFs are largely involved in these processes. These results indicate that the miRNA-mediated LDR response is functionally engaged with both positive and negative biological processes. 
A

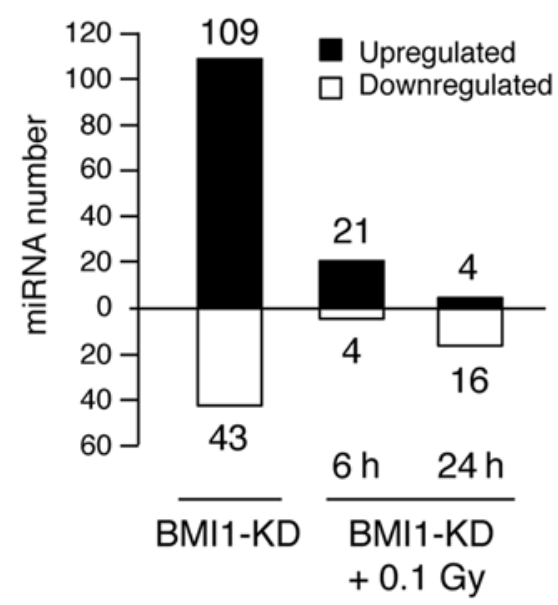

B

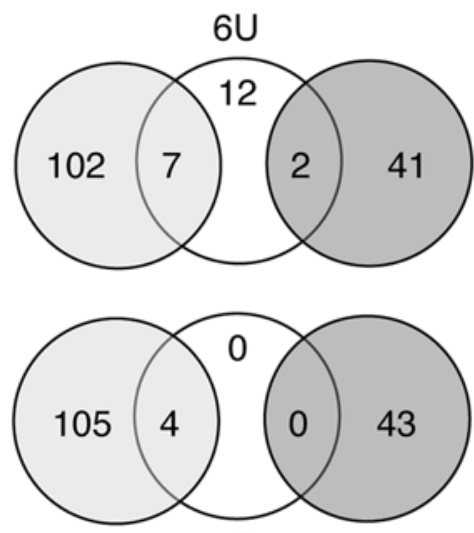

$6 \mathrm{D}$
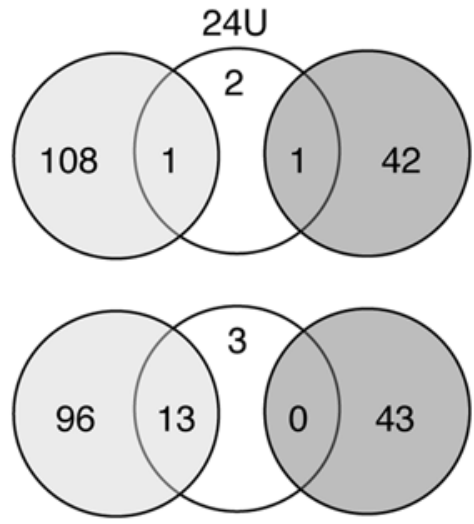

24D
Upregulated miRNAs in BMl1-KD cells
Downregulated miRNAs in BMI1-KD cells
LDR-induced regulated miRNAs in BMI1-KD cells

Figure 4. Comparative analysis for LDR-induced altered miRNAs. (A) The graph shows the number of significantly altered miRNAs in BMI1-knockdown NHDFs (BMI1-KD) and BMI1-KD 6 and 24 h post-irradiation. (B) Venn diagram showing unique and shared miRNAs between the 3 groups. The additional incubation time in hours, 6 or 24, after irradiation. $\mathrm{U}$ or D indicates upregulated miRNA or downregulated miRNA, respectively. For example, $6 \mathrm{U}$ indicates the number of upregulated miRNAs in BMI1-knockdown cells $6 \mathrm{~h}$ post-irradiation.

Negative regulation of

(1) Apoptotic process

(2) Cell growth

(3) Cell proliferation

(4) Cell cycle

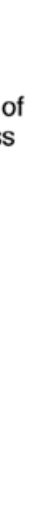

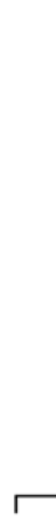

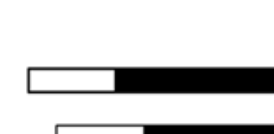

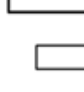

8

(\%) 100.0
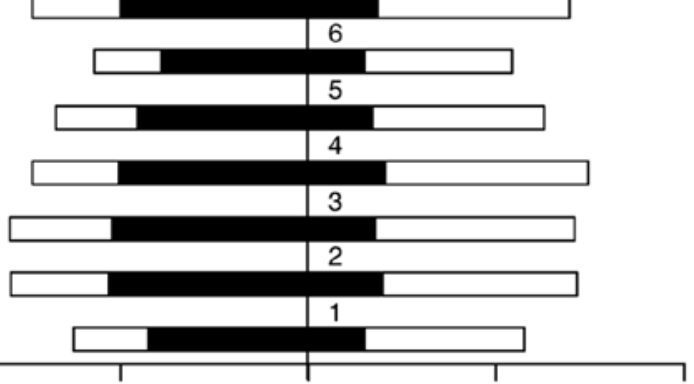

50.0

0.0

50.0

$100.0(\%)$

\begin{abstract}
Positive regulation of
(2) Apoptotic process

(4) Cell growth

(6) Cell proliferation

(8) Cell cycle
\end{abstract}

At $6 \mathrm{~h}$ after irradiation

At $24 \mathrm{~h}$ after irradiation

Figure 5. Bioinformatics analysis of LDR-induced miRNA alterations in BMI1-knockdown NHDFs. The predicted target genes of the altered miRNAs were grouped into the indicated biological functions using the bioinformatics tool AmiGO. The value of percentage describes the number of involved genes in each category/the number of total predicted target genes of the miRNAs.

A KEGG pathway annotation of the miRNA targets was then performed based on scoring of the pathways collected in the KEGG databases using the DAVID tool. The EASE Score, which is a modified Fisher Extract p-value, was fixed at 0.1, and meaningful KEGG pathways showing a value $>1 \%$ (percentage of involved target genes/total genes involved in each pathway) were selected. From these analytic processes, unique and shared pathways were found to be involved with either the 6BP- or 242BP-NHDFs. Axon guidance, cell adhesion molecules, MAPK signaling pathway, and pathways involved in cancer were the main overrepresented pathways in the targets of the upregulated miRNAs in 6BP-NHDFs (Table III), whereas, Wnt,
mTOR, MAPK and ErbB signaling pathways were common in the targets of the downregulated miRNAs in 6BP-NHDFs (Table IV), suggesting that these pathways are significantly regulated after $6 \mathrm{~h}$ of post-irradiation with LDR. The full lists for the identified pathways are presented in Tables III and IV. We also found that the Wnt, MAPK and ErbB signaling pathways were unique specific to several upregulated miRNAs in 24BP-NHDFs (Table V); however, these pathways were mostly shared involving the targets of the downregulated miRNAs in 24BP-NHDFs (Table VI). Overall, the results of the pathway analysis demonstrate possible roles for the differentially expressed miRNAs in the LDR response. 
Table III. Functional annotation chart for miRNAs that were upregulated in BMI1-knockdown NHDF cells 6 h after irradiation with 0.1 Gy radiation.

\begin{tabular}{|c|c|c|c|c|c|}
\hline $\begin{array}{l}\text { miRNA } \\
\text { (Homo sapiens) }\end{array}$ & $\begin{array}{l}\text { Putative } \\
\text { target genes }\end{array}$ & KEGG pathway & $\begin{array}{l}\text { Genes involved } \\
\text { in the pathway }\end{array}$ & $\begin{array}{l}\% \text { of involved genes/ } \\
\text { total genes }\end{array}$ & p-value \\
\hline $\operatorname{miR}-1225-3 p$ & 183 & MAPK signaling pathway & 7 & 3.8 & $6.20 \mathrm{E}-02$ \\
\hline miR-134 & 245 & $\begin{array}{l}\text { Chemokine signaling pathway } \\
\text { Jak-STAT signaling pathway } \\
\text { ECM-receptor interaction }\end{array}$ & $\begin{array}{l}7 \\
6 \\
4\end{array}$ & $\begin{array}{l}2.9 \\
2.4 \\
1.6\end{array}$ & $\begin{array}{l}1.70 \mathrm{E}-02 \\
2.90 \mathrm{E}-02 \\
6.70 \mathrm{E}-02\end{array}$ \\
\hline miR-1825 & 321 & $\begin{array}{l}\text { Pathways in cancer } \\
\text { MAPK signaling pathway }\end{array}$ & $\begin{array}{l}9 \\
8\end{array}$ & $\begin{array}{l}2.8 \\
2.5\end{array}$ & $\begin{array}{l}6.90 \mathrm{E}-02 \\
6.40 \mathrm{E}-02\end{array}$ \\
\hline miR-202-3p & 223 & Axon guidance & 5 & 2.2 & $7.80 \mathrm{E}-02$ \\
\hline $\operatorname{miR}-222-5 p$ & 32 & - & - & - & - \\
\hline $\operatorname{miR}-23 a-5 p$ & 99 & - & - & - & - \\
\hline $\operatorname{miR}-3180-5 p$ & 489 & $\begin{array}{l}\text { Axon guidance } \\
\text { Cell adhesion molecules }\end{array}$ & $\begin{array}{l}9 \\
7\end{array}$ & $\begin{array}{l}1.8 \\
1.4\end{array}$ & $\begin{array}{l}8.80 \mathrm{E}-03 \\
8.00 \mathrm{E}-02\end{array}$ \\
\hline miR-3676 & 7 & - & - & - & - \\
\hline $\operatorname{miR}-370$ & 199 & $\begin{array}{l}\text { Pathways in cancer } \\
\text { VEGF signaling pathway }\end{array}$ & $\begin{array}{l}7 \\
4\end{array}$ & $\begin{array}{c}3.5 \\
2\end{array}$ & $\begin{array}{l}5.60 \mathrm{E}-02 \\
2.50 \mathrm{E}-02\end{array}$ \\
\hline $\operatorname{miR}-374 b-5 p$ & 867 & $\begin{array}{l}\text { Pathways in cancer } \\
\text { MAPK signaling pathway } \\
\text { Wnt signaling pathway } \\
\text { TGF- } \beta \text { signaling pathway }\end{array}$ & $\begin{array}{l}31 \\
22 \\
15 \\
11\end{array}$ & $\begin{array}{l}3.6 \\
2.5 \\
1.7 \\
1.3\end{array}$ & $\begin{array}{l}2.00 \mathrm{E}-04 \\
1.10 \mathrm{E}-02 \\
9.50 \mathrm{E}-03 \\
6.40 \mathrm{E}-03\end{array}$ \\
\hline miR-3926 & 400 & $\begin{array}{l}\text { Pathways in cancer } \\
\text { Huntington's disease }\end{array}$ & $\begin{array}{r}12 \\
8\end{array}$ & $\begin{array}{l}3 \\
2\end{array}$ & $\begin{array}{l}5.00 \mathrm{E}-02 \\
5.80 \mathrm{E}-02\end{array}$ \\
\hline miR-409-5p & 34 & MAPK signaling pathway & 3 & 8.8 & $6.20 \mathrm{E}-02$ \\
\hline $\operatorname{miR}-4270$ & 423 & $\begin{array}{l}\text { Axon guidance } \\
\text { Insulin signaling pathway }\end{array}$ & $\begin{array}{l}8 \\
6\end{array}$ & $\begin{array}{l}1.9 \\
1.4\end{array}$ & $\begin{array}{l}5.50 \mathrm{E}-03 \\
7.40 \mathrm{E}-02\end{array}$ \\
\hline $\operatorname{miR}-431-3 p$ & 2 & - & - & - & - \\
\hline miR-623 & 26 & - & - & - & - \\
\hline $\operatorname{miR}-629-3 p$ & 441 & $\begin{array}{l}\text { PPAR signaling pathway } \\
\text { Oocyte meiosis } \\
\text { Riboflavin metabolism }\end{array}$ & $\begin{array}{l}6 \\
6 \\
3\end{array}$ & $\begin{array}{l}1.4 \\
1.4 \\
0.7\end{array}$ & $\begin{array}{l}1.20 \mathrm{E}-02 \\
6.90 \mathrm{E}-02 \\
4.00 \mathrm{E}-02\end{array}$ \\
\hline miR-634 & 207 & $\begin{array}{l}\text { GnRH signaling pathway } \\
\text { Long-term potentiation }\end{array}$ & $\begin{array}{l}5 \\
4\end{array}$ & $\begin{array}{l}2.4 \\
1.9\end{array}$ & $\begin{array}{l}4.10 \mathrm{E}-02 \\
6.20 \mathrm{E}-02\end{array}$ \\
\hline $\operatorname{miR}-642 b-3 p$ & 272 & Cell adhesion molecules & 5 & 1.8 & $5.70 \mathrm{E}-02$ \\
\hline $\operatorname{miR}-650$ & 266 & $\begin{array}{l}\text { Cell adhesion molecules } \\
\text { Glycerophospholipid metabolism }\end{array}$ & $\begin{array}{l}6 \\
4\end{array}$ & $\begin{array}{l}2.3 \\
1.5\end{array}$ & $\begin{array}{l}2.90 \mathrm{E}-02 \\
6.00 \mathrm{E}-02\end{array}$ \\
\hline miR-664a-3p & 1,109 & $\begin{array}{l}\text { Regulation of actin cytoskeleton } \\
\text { Apoptosis } \\
\text { mTOR signaling pathway }\end{array}$ & $\begin{array}{r}20 \\
9 \\
7\end{array}$ & $\begin{array}{l}1.8 \\
0.8 \\
0.6\end{array}$ & $\begin{array}{l}2.10 \mathrm{E}-02 \\
9.40 \mathrm{E}-02 \\
5.80 \mathrm{E}-02\end{array}$ \\
\hline $\operatorname{miR}-770-5 p$ & 257 & Neurotrophin signaling pathway & 7 & 2.7 & $3.80 \mathrm{E}-03$ \\
\hline
\end{tabular}

\section{Discussion}

We have uncovered a new role for BMI1 and miRNAs in the LDR response. BMI1 is a well-known factor involved in radioresistance (11-13), and therefore, we hypothesized that ablation of BMI1 induces radiosensitivity even at a low dose (0.1 Gy of $\gamma$-radiation). Our data, however, unexpectedly revealed that cells stably expressing shBMI1 do not exhibit high sensitivity to irradiation. Unchanged cell viability and cell cycle distribution were observed in BMI1-knockdown cells following exposure to 0.1 Gy of radiation, suggesting that BMI1 plays a nonessen- tial role in these specific cellular phenotypes in response to LDR. Previous reports, which demonstrated BMI1-mediated radioresistance, examined its effectiveness at relatively high doses ( $\geq 1$ Gy). Facchino et al demonstrated that BMI1 overexpression confers radioresistance in normal and cancerous neural stem cells following $3 \mathrm{~Gy}$ irradiation (11). Liu et al used a series of radiation doses (1 to $20 \mathrm{~Gy}$ ) to demonstrate that BMI1 promotes radioresistance in the MCF-7 breast cancer cell line (12). Furthermore, Chagraoui et al showed that radiation sensitivity is increased in Bmil-knockout mice after irradiation with 2 Gy of $\gamma$-radiation (13). Therefore, the 
Table IV. Functional annotation chart for miRNAs that were downregulated in BMI1-knockdown NHDF cells $6 \mathrm{~h}$ after irradiation with 0.1 Gy.

\begin{tabular}{|c|c|c|c|c|c|}
\hline $\begin{array}{l}\text { miRNA } \\
\text { (Homo sapiens) }\end{array}$ & $\begin{array}{c}\text { Putative } \\
\text { target genes }\end{array}$ & KEGG pathway & $\begin{array}{l}\text { Genes involved } \\
\text { in the pathway }\end{array}$ & $\begin{array}{c}\% \text { of involved genes/ } \\
\text { total genes }\end{array}$ & p-value \\
\hline \multirow[t]{5}{*}{$\operatorname{miR}-17-3 p$} & \multirow[t]{5}{*}{307} & MAPK signaling pathway & 10 & 3.3 & $1.3 \mathrm{E}-2$ \\
\hline & & Pathways in cancer & 9 & 2.9 & $9.6 \mathrm{E}-2$ \\
\hline & & Insulin signaling pathway & 7 & 2.9 & $1.2 \mathrm{E}-2$ \\
\hline & & mTOR signaling pathway & 6 & 2.0 & $8.2 \mathrm{E}-4$ \\
\hline & & VEGF signaling pathway & 4 & 1.3 & $9.2 \mathrm{E}-2$ \\
\hline \multirow[t]{6}{*}{$\operatorname{miR}-329$} & \multirow[t]{6}{*}{706} & Pathways in cancer & 25 & 3.5 & 5.60E-04 \\
\hline & & MAPK signaling pathway & 21 & 3 & $1.20 \mathrm{E}-03$ \\
\hline & & Insulin signaling pathway & 14 & 2 & $9.80 \mathrm{E}-04$ \\
\hline & & Wnt signaling pathway & 13 & 1.8 & $7.50 \mathrm{E}-03$ \\
\hline & & ErbB signaling pathway & 9 & 1.3 & $1.20 \mathrm{E}-02$ \\
\hline & & Cell cycle & 9 & 1.3 & $7.80 \mathrm{E}-02$ \\
\hline $\operatorname{miR}-450 a-5 p$ & 21 & - & - & - & - \\
\hline \multirow[t]{9}{*}{$\operatorname{miR}-758$} & \multirow[t]{9}{*}{375} & Pathways in cancer & 15 & 4 & $3.40 \mathrm{E}-03$ \\
\hline & & Insulin signaling pathway & 8 & 2.1 & $1.40 \mathrm{E}-02$ \\
\hline & & Colorectal cancer & 7 & 1.9 & $5.10 \mathrm{E}-03$ \\
\hline & & Wnt signaling pathway & 7 & 1.9 & $6.70 \mathrm{E}-02$ \\
\hline & & ECM-receptor interaction & 5 & 1.3 & 7.60E-02 \\
\hline & & ErbB signaling pathway & 5 & 1.3 & $8.40 \mathrm{E}-02$ \\
\hline & & Prostate cancer & 5 & 1.3 & 8.90E-02 \\
\hline & & Endometrial cancer & 4 & 1.1 & 7.60E-02 \\
\hline & & mTOR signaling pathway & 4 & 1.1 & 7.60E-02 \\
\hline
\end{tabular}

Table V. Functional annotation chart for miRNAs that were upregulated in BMI1-knockdown NHDF cells $24 \mathrm{~h}$ after irradiation with 0.1 Gy radiation.

\begin{tabular}{|c|c|c|c|c|c|}
\hline $\begin{array}{l}\text { miRNA } \\
\text { (Homo sapiens) }\end{array}$ & $\begin{array}{c}\text { Putative } \\
\text { target genes }\end{array}$ & KEGG pathway & $\begin{array}{l}\text { Genes involved } \\
\text { in the pathway }\end{array}$ & $\begin{array}{c}\% \text { of involved genes/ } \\
\text { total genes }\end{array}$ & p-value \\
\hline $\operatorname{miR}-100-3 p$ & 187 & $\begin{array}{l}\text { Pathways in cancer } \\
\text { Cell cycle } \\
\text { Wnt signaling pathway }\end{array}$ & $\begin{array}{l}7 \\
5 \\
4\end{array}$ & $\begin{array}{l}3.7 \\
2.7 \\
2.1\end{array}$ & $\begin{array}{l}1.50 \mathrm{E}-02 \\
7.30 \mathrm{E}-03 \\
6.80 \mathrm{E}-02\end{array}$ \\
\hline $\operatorname{miR}-1825$ & 390 & $\begin{array}{l}\text { Pathways in cancer } \\
\text { MAPK signaling pathway } \\
\text { Arrhythmogenic right } \\
\text { ventricular cardiomyopathy }\end{array}$ & $\begin{array}{l}13 \\
10 \\
6\end{array}$ & $\begin{array}{l}3.3 \\
2.6 \\
1.5\end{array}$ & $\begin{array}{l}1.30 \mathrm{E}-02 \\
4.80 \mathrm{E}-02 \\
1.10 \mathrm{E}-02\end{array}$ \\
\hline $\operatorname{miR}-3937$ & 27 & - & - & - & - \\
\hline $\operatorname{miR}-4323$ & 187 & $\begin{array}{l}\text { Axon guidance } \\
\text { ErbB signaling pathway } \\
\text { GnRH signaling pathway }\end{array}$ & $\begin{array}{l}5 \\
4 \\
4\end{array}$ & $\begin{array}{l}2.7 \\
2.1 \\
2.1\end{array}$ & $\begin{array}{l}3.70 \mathrm{E}-02 \\
5.30 \mathrm{E}-02 \\
7.10 \mathrm{E}-02\end{array}$ \\
\hline
\end{tabular}

role of BMI1 in LDR response was previously unexplored. Our data, however, indicate that the role of BMI1 in response to high-dose radiation is different than its role in response to LDR.

Generally, the cellular and physiological effects of LDR are controversial, and three hypotheses have been provided to explain these LDR effects $(34,35)$. Our data do not support the LNT model, but do not refute the threshold model or the hormesis model (also known as adaptive response model). Because a modest sensitivity to LDR is still generated in the absence of radioresistance-inducing BMI1, the LNT hypothesis, which indicates that the cytotoxic effects of high-dose irradiation applies to LDR, is not reflected in our study. Rather, our results suggest that cells may have a threshold against LDR (threshold model); however, additional data from our miRNA expression analysis has some divergence from the threshold models. Although we found no meaningful alterations in cell viability or cell cycle arrest in response to irradiation even in the absence of BMI1, these results do not directly indicate that LDR does not affect cells. 
Table VI. Functional annotation chart for miRNAs that were downregulated in BMI1-knockdown NHDF cells $24 \mathrm{~h}$ after irradiation with 0.1 Gy radiation.

\begin{tabular}{|c|c|c|c|c|c|}
\hline $\begin{array}{l}\text { miRNA } \\
\text { (Homo sapiens) }\end{array}$ & $\begin{array}{c}\text { Putative } \\
\text { target genes }\end{array}$ & KEGG pathway & $\begin{array}{l}\text { Genes involved } \\
\text { in the pathway }\end{array}$ & $\begin{array}{c}\% \text { of involved genes/ } \\
\text { total genes }\end{array}$ & p-value \\
\hline $\operatorname{miR}-1208$ & 516 & $\begin{array}{l}\text { MAPK signaling pathway } \\
\text { Wnt signaling pathway } \\
\text { ErbB signaling pathway } \\
\text { TGF- } \beta \text { signaling pathway } \\
\text { mTOR signaling pathway } \\
\text { VEGF signaling pathway }\end{array}$ & $\begin{array}{l}13 \\
10 \\
8 \\
8 \\
6 \\
6\end{array}$ & $\begin{array}{l}2.5 \\
1.9 \\
1.6 \\
1.6 \\
1.2 \\
1.2\end{array}$ & $\begin{array}{l}5.70 \mathrm{E}-02 \\
2.10 \mathrm{E}-02 \\
8.90 \mathrm{E}-03 \\
8.90 \mathrm{E}-03 \\
1.30 \mathrm{E}-02 \\
5.20 \mathrm{E}-02\end{array}$ \\
\hline miR-1224-5p & 263 & Axon guidance & 5 & 1.9 & $5.00 \mathrm{E}-02$ \\
\hline $\operatorname{miR}-181 a-3 p$ & 1 & - & - & - & - \\
\hline miR-299-3p & 238 & Purine metabolism & 5 & 2.1 & $6.20 \mathrm{E}-02$ \\
\hline miR-3188 & 266 & Tight junction & 6 & 2.3 & 4.70E-02 \\
\hline $\operatorname{miR}-32-5 p$ & 774 & Focal adhesion & 16 & 2.1 & $1.90 \mathrm{E}-03$ \\
\hline $\operatorname{miR}-34 c-5 p$ & 412 & $\begin{array}{l}\text { Adherens junction } \\
\text { Cell cycle } \\
\text { Wnt signaling pathway }\end{array}$ & $\begin{array}{l}9 \\
7 \\
7\end{array}$ & $\begin{array}{l}2.2 \\
1.7 \\
1.7\end{array}$ & $\begin{array}{l}1.70 \mathrm{E}-04 \\
4.50 \mathrm{E}-02 \\
9.40 \mathrm{E}-02\end{array}$ \\
\hline $\operatorname{miR}-3652$ & 250 & $\begin{array}{l}\text { ErbB signaling pathway } \\
\text { Insulin signaling pathway }\end{array}$ & $\begin{array}{l}5 \\
5\end{array}$ & $\begin{array}{l}2 \\
2\end{array}$ & $\begin{array}{l}2.60 \mathrm{E}-02 \\
9.70 \mathrm{E}-02\end{array}$ \\
\hline $\operatorname{miR}-369-3 p$ & 1,171 & $\begin{array}{l}\text { Pathways in cancer } \\
\text { MAPK signaling pathway } \\
\text { Jak-STAT signaling pathway } \\
\text { TGF- } \beta \text { signaling pathway } \\
\text { ErbB signaling pathway }\end{array}$ & $\begin{array}{l}34 \\
23 \\
16 \\
15 \\
12\end{array}$ & $\begin{array}{c}2.9 \\
2 \\
1.4 \\
1.3 \\
1\end{array}$ & $\begin{array}{l}1.10 \mathrm{E}-03 \\
5.80 \mathrm{E}-02 \\
3.40 \mathrm{E}-02 \\
4.10 \mathrm{E}-04 \\
1.10 \mathrm{E}-02\end{array}$ \\
\hline $\operatorname{miR}-369-5 p$ & 2 & - & - & - & - \\
\hline $\operatorname{miR}-409-5 p$ & 42 & - & - & - & - \\
\hline miR-454-3p & 546 & $\begin{array}{l}\text { Endocytosis } \\
\text { TGF- } \beta \text { signaling pathway } \\
\text { mTOR signaling pathway } \\
\text { Inositol phosphate metabolism }\end{array}$ & $\begin{array}{l}16 \\
7 \\
5 \\
5\end{array}$ & $\begin{array}{l}2.9 \\
1.3 \\
0.9 \\
0.9\end{array}$ & $\begin{array}{l}2.80 \mathrm{E}-04 \\
4.10 \mathrm{E}-02 \\
6.50 \mathrm{E}-02 \\
7.20 \mathrm{E}-02\end{array}$ \\
\hline miR-539-5p & 632 & Regulation of actin cytoskeleton & 12 & 1.9 & 7.50E-02 \\
\hline $\operatorname{miR}-548 c-3 p$ & 1,065 & $\begin{array}{l}\text { Pathways in cancer } \\
\text { MAPK signaling pathway } \\
\text { Wnt signaling pathway } \\
\text { Cell cycle } \\
\text { Ubiquitin mediated proteolysis } \\
\text { p53 signaling pathway } \\
\text { ErbB signaling pathway } \\
\text { TGF- } \beta \text { signaling pathway }\end{array}$ & $\begin{array}{l}38 \\
24 \\
22 \\
14 \\
14 \\
11 \\
11 \\
11\end{array}$ & $\begin{array}{l}3.6 \\
2.3 \\
2.1 \\
1.3 \\
1.3 \\
1 \\
1 \\
1\end{array}$ & $\begin{array}{l}1.60 \mathrm{E}-05 \\
2.10 \mathrm{E}-02 \\
6.60 \mathrm{E}-05 \\
1.90 \mathrm{E}-02 \\
3.70 \mathrm{E}-02 \\
3.70 \mathrm{E}-03 \\
2.00 \mathrm{E}-02 \\
2.00 \mathrm{E}-02\end{array}$ \\
\hline miR-623 & 30 & - & - & - & - \\
\hline miR-629-3p & 563 & PPAR signaling pathway & 6 & 1.1 & 3.20E-02 \\
\hline
\end{tabular}

Instead, our data indicate that LDR influences miRNA expression profiles. Our time course miRNA microarray analyses clearly show that numerous miRNAs are differentially expressed after exposure to $0.1 \mathrm{~Gy}$ of $\gamma$-radiation, despite the lack of change in cell viability and cell cycle distribution under the same experimental conditions. Moreover, 32 of these miRNAs were differentially expressed more than 20-fold after irradiation, indicating that the differentially expressed miRNAs may be involved in the low LDR sensitivity in these cells. Our bioinformatics analyses of the differentially expressed miRNAs revealed that the target genes of the altered miRNAs are functionally involved in both positive and negative regulation of cell growth, proliferation, apoptosis, and the cell cycle. Although the differences in each category are dependent on the process direction (positive or negative), the differences were less than $10 \%$. These results suggest that the interplay between the positive and the negative regulation of these processes mediates this modest sensitivity to LDR in cells. Therefore, we conclude that LDR influences the miRNA expression profiles to minimize the cytotoxicity on cells. This conclusion supports the hormesis (or adaptive response) hypothesis of the LDR effect, but 
because our study used single irradiation conditions, it is not confirmed. Additional sequential LDR is necessary to confirm the hormesis effects, and this will help discriminate between the threshold model and the hormesis model.

In summary, we demonstrated that the radioresistance-inducing protein BMI1 is not critical for the LDR response. We also demonstrated that LDR induces minimal cytotoxic effects on cells; however, these radiation effects result from the interplay between miRNAs and LDR. Although additional investigation should be performed to further examine the LDR effect, our results offer novel information on miRNA-mediated LDR response in NHDFs.

\section{Acknowledgements}

This study was supported by grant no. 20131610101840 from the Ministry of Trade, Industry and Energy of Republic of Korea. S.B. was supported by the KU Research Professor Program of Konkuk University.

\section{References}

1. $\mathrm{Xu} \mathrm{CR}$, Lee $\mathrm{S}$, Ho $\mathrm{C}$, et al: Bmil functions as an oncogene independent of Ink4A/Arf repression in hepatic carcinogenesis. Mol Cancer Res 7: 1937-1945, 2009.

2. Dimri GP, Martinez JL, Jacobs JJ, et al: The Bmi-1 oncogene induces telomerase activity and immortalizes human mammary epithelial cells. Cancer Res 62: 4736-4745, 2002.

3. Cao LX, Bombard J, Cintron K, Sheedy J, Weetall ML and Davis TW: BMI1 as a novel target for drug discovery in cancer. J Cell Biochem 112: 2729-2741, 2011.

4. Siddique HR and Saleem M: Role of BMI1, a stem cell factor, in cancer recurrence and chemoresistance: preclinical and clinical evidences. Stem Cells 30: 372-378, 2012.

5. Vrzalikova K, Skarda J, Ehrmann J, et al: Prognostic value of Bmi-1 oncoprotein expression in NSCLC patients: a tissue microarray study. J Cancer Res Clin Oncol 134: 1037-1042, 2008.

6. Wang H, Pan K, Zhang HK, et al: Increased polycomb-group oncogene Bmi-1 expression correlates with poor prognosis in hepatocellular carcinoma. J Cancer Res Clin Oncol 134 535-541, 2008.

7. Chowdhury M, Mihara K, Yasunaga S, Ohtaki M, Takihara Y and Kimura A: Expression of Polycomb-group (PcG) protein BMI-1 predicts prognosis in patients with acute myeloid leukemia. Leukemia 21: 1116-1122, 2007.

8. Jacobs JJL, Kieboom K, Marino S, DePinho RA and van Lohuizen M: The oncogene and Polycomb-group gene bmi-1 regulates cell proliferation and senescence through the ink4a locus. Nature 397: 164-168, 1999.

9. Douglas D, Hsu JH, Hung L, et al: BMI-1 promotes ewing sarcoma tumorigenicity independent of CDKN2A repression. Cancer Res 68: 6507-6515, 2008.

10. Chou CH, Yang NK, Liu TY, et al: Chromosome instability modulated by BMI1-AURKA signaling drives progression in head and neck cancer. Cancer Res 73: 953-966, 2013.

11. Facchino S, Abdouh M, Chatoo W and Bernier G: BMI1 confers radioresistance to normal and cancerous neural stem cells through recruitment of the DNA damage response machinery. J Neurosci 30: 10096-10111, 2010.

12. Liu ZG, Liu L, Xu LH, et al: Bmi-1 induces radioresistance in MCF-7 mammary carcinoma cells. Oncol Rep 27: 1116-1122, 2012.
13. Chagraoui J, Hebert J, Girard S and Sauvageau G: An anticlastogenic function for the Polycomb group gene Bmil. Proc Natl Acad Sci USA 108: 5284-5289, 2011.

14. Alajez NM, Shi W, Hui AB, et al: Targeted depletion of BMI1 sensitizes tumor cells to P53-mediated apoptosis in response to radiation therapy. Cell Death Differ 16: 1469-1479, 2009.

15. Cuttler JM and Pollycove M: Nuclear energy and health: and the benefits of low-dose radiation hormesis. Dose Response 7: 52-89, 2009.

16. Bonner WM: Low-dose radiation: thresholds, bystander effects, and adaptive responses. Proc Natl Acad Sci USA 100: 4973-4975, 2003.

17. Bonner WM: Phenomena leading to cell survival values which deviate from linear-quadratic models. Mutat Res 568: 33-39, 2004.

18. Wodarz D, Sorace R and Komarova NL: Dynamics of cellular responses to radiation. PLoS Comput Biol 10: e1003513, 2014.

19. Venkat S, Apte SK, Chaubey RC and Chauhan PS: Radioadaptive response in human lymphocytes in vitro. J Environ Pathol Toxicol Oncol 20: 165-175, 2001.

20. Tapio S and Jacob V: Radioadaptive response revisited. Radiat Environ Biophys 46: 1-12, 2007.

21. Marples B and Collis SJ: Low-dose hyper-radiosensitivity: past, present, and future. Int J Radiat Oncol Biol Phys 70: 1310-1318, 2008.

22. Fabian MR, Sonenberg N and Filipowicz W: Regulation of mRNA translation and stability by microRNAs. Annu Rev Biochem 79: 351-379, 2010.

23. Cai Y, Yu X, Hu S and Yu J: A brief review on the mechanisms of miRNA regulation. Genomics Proteomics Bioinformatics 7: 147-154, 2009.

24. Cha HJ, Seong KM, Bae S, et al: Identification of specific microRNAs responding to low and high dose gammairradiation in the human lymphoblast line IM9. Oncol Rep 22: 863-868, 2009

25. Cha HJ, Shin $\mathrm{S}$, Yoo $\mathrm{H}$, et al: Identification of ionizing radiation-responsive microRNAs in the IM9 human B lymphoblastic cell line. Int J Oncol 34: 1661-1668, 2009.

26. Shin S, Cha HJ, Lee EM, et al: Alteration of miRNA profiles by ionizing radiation in A549 human non-small cell lung cancer cells. Int J Oncol 35: 81-86, 2009.

27. Wang J, He J, Su F, et al: Repression of ATR pathway by miR-185 enhances radiation-induced apoptosis and proliferation inhibition. Cell Death Dis 4: e699, 2013.

28. Kwon JE, Kim BY, Kwak SY, Bae IH and Han YH: Ionizing radiation-inducible microRNA miR-193a-3p induces apoptosis by directly targeting Mcl-1. Apoptosis 18: 896-909, 2013.

29. Lee EJ, Cha HJ, Ahn KJ, An IS, An S and Bae S: Oridonin exerts protective effects against hydrogen peroxideinduced damage by altering microRNA expression profiles in human dermal fibroblasts. Int J Mol Med 32: 1345-1354, 2013.

30. Paraskevopoulou MD, Georgakilas G, Kostoulas N, et al: DIANA-microT web server v5.0: service integration into miRNA functional analysis workflows. Nucleic Acids Res 41: W169-W173, 2013

31. Huang da W, Sherman BT and Lempicki RA: Systematic and integrative analysis of large gene lists using DAVID bioinformatics resources. Nat Protoc 4: 44-57, 2009.

32. Ochiai H, Takenobu H, Nakagawa A, et al: Bmil is a MYCN target gene that regulates tumorigenesis through repression of KIF1B beta and TSLC1 in neuroblastoma. Oncogene 29: 2681-2690, 2010.

33. Biehs B, Hu JK, Strauli NB, et al: BMI1 represses Ink4a/Arf and Hox genes to regulate stem cells in the rodent incisor. Nat Cell Biol 15: 846-852, 2013.

34. Cleaver JE: Biology and genetics in the biological effects of ionizing radiation (BEIR VII) report. Health Physics 89: S32, 2005.

35. Feinendegen LE: Evidence for beneficial low level radiation effects and radiation hormesis. Br J Radiol 78: 3-7, 2005. 